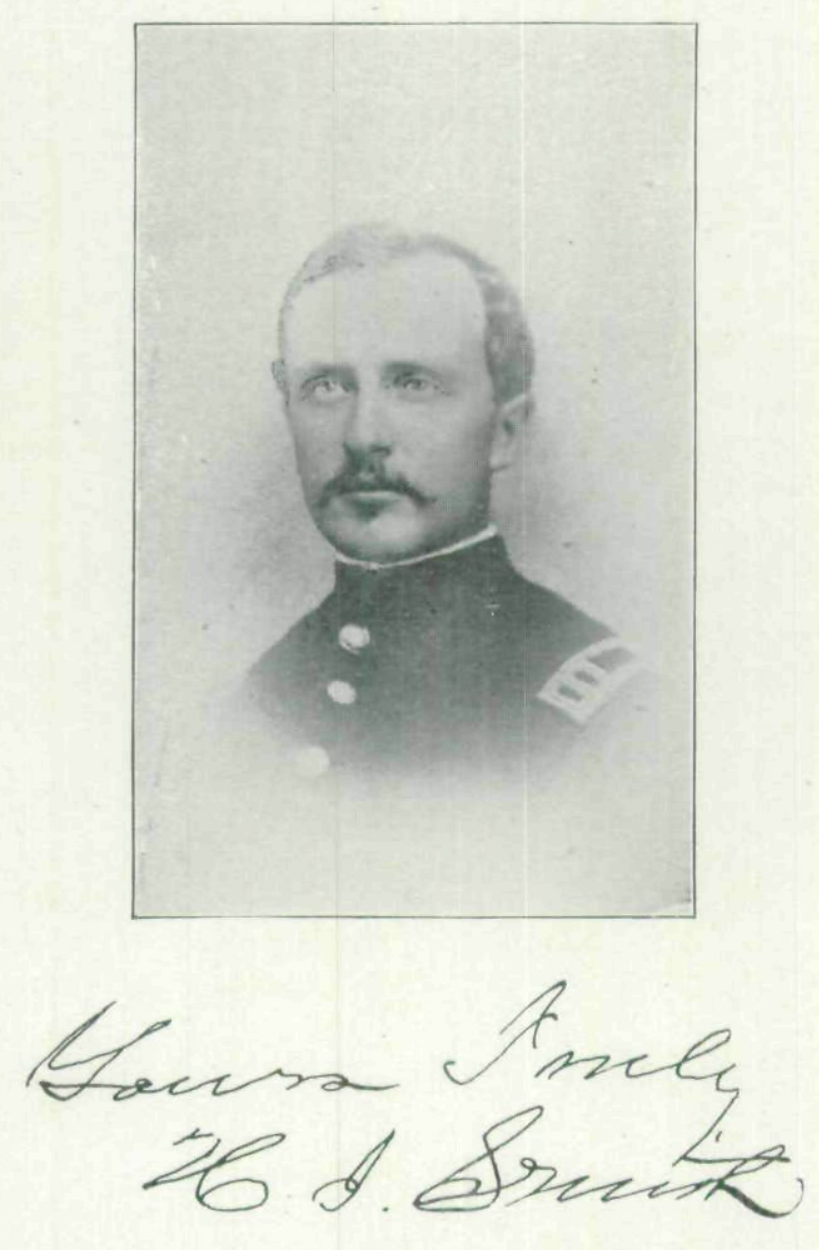




\section{THE SAD WAR EXPERIENCES OF TWO IOWA BROTHERS.}

BY OAPT. H. I. SMITH, OF MASON CITY, IOWA.

There were only two of us, Peter and I. Notwithstanding that we were the only sons of a widowed mother, with two younger sisters, living on a farm in Cerro Gordo, then a frontier county in the State, we had both enlisted early in the war, and were among the first who started for the front. I had gone first, early in 1861, with mother's consent and blessing, with the understanding that my brother should remain at home and work the farm. He staid, apparently contented, until the following winter, when I returned on a furlough from Mound City hospital, where I had been for treatment for a severe gun-shot wound in the right shoulder, received at the battle of Belmont, Mo., November 7, 1861.

They laid me on mother's bed when I was brought home. My brother was away at the time and did not return until evening. When he came home, mother told him to go into her bedroom and see who was there. The first intimation he had that I had returned was when he saw me there. I never shall forget his looks at that time. I was very much emaciated from the effects of my wound and the exposure and neglect following, having been left on the battlefield in the hands of the Rebels and receiving no medical attendance until over twenty-four hours after the battle. He was very much affected at seeing me in that condition. He was then about nineteen years of age, with a form and physique the perfection of manhood and health; well rounded out by a life of toil and privation on the frontier of Iowa. His face at first flushed; then every drop of blood seemed to leave it and it was blanched and grew hard, and the bloodless lips set in straight, cruel lines. It was some time before he could control his feelings so he dared attempt to speak. He finally calmed down and 
talked to me about the war, asked where my regiment was, and a few particulars about my route home, when he said: "I shall have revenge for this. I have been chafing to get away tothe front ever since you went to the war, and I can stand it no longer." He said: "Say nothing to mother and sisters about it at present," and he was gone.

He went straight to the front, joined my regiment, the 7th Iowa Infantry, in time to take an active part in the dangerous and arduous campaign with General Grant, in the siege and capture of Forts Henry and Donelson, being assigned to Lauman's Brigade which led the charge in the capture of Fort. Donelson. He endured all the privations of the rain, mud and snow, away from tents and supplies, in the most inclement season of the year, incident to that campaign; from there he went to Shiloh, where he was wounded in the shoulder by a fragment of a shell, the first day of the battle, being in that portion of the field designated by the Rebels as the "Hornet's nest," on account of the stubborn resistance encountered at that part of our line-they having been unable to break through at that point. Notwithstanding he was wounded and nearly disabled, he refused to go to the rear, but staid with his company and fought all through both days of the battle.

By this time I had sufficiently recovered from my wound so as to be able for light duty, and had returned to my regiment. During the night, between the two days' fight, our regiment was ordered not to move from their tracks, and not a man left the ranks. At dark the battle gradually subsided from a continuous roar of artillery and musketry to a desultory firing here and there along the line, and the men were allowed to lie down on their arms and take a much-needed rest. My brother's place in the ranks came in a road, which had been used through the day by the troops, artillery, ammunition wagons and ambulances, passing back and forth, and, being wet, had been churned into a perfect pudding of mud, on which he spread his blanket and laid down. The night set in dark and rainy, and no fires were allowed in the front. Its stillness was 
broken by occasional musket shots and the regular firing of nine-inch shells every fifteen minutes from the gun-boats, Lexington and Tyler, in the river, which went screeching overhead and bursting among the enemy in the woods beyond, and the moaning of the wounded as they were carried through the lines to the hospital tents in the rear. All night long the tramp of the ambulance corps with the stretchers and suffering loads of humanity could be heard, and the pitiless rain poured down incessantly, making both wounded and well uncomfortable. In the morning my brother got up out of his mud wallow, soaking wet, and so stiff and sore he could scarcely move, leaving his blanket where it laid, but could not be induced to go to the hospital or to the rear. He staid with the company and participated in the battle until the Rebels were routed and driven from the field. Sunday morning when the battle began our regiment was away from our camp on inspection, and was ordered from there to the left of the army without going back to quarters. On our return to our tents after the battle, we found they had been occupied by the enemy. They had gone so suddenly that they had left many of their wounded in our camp. From my tent they had taken everything they could carry, including my violin, and left one of their wounded, a mere youth, whom we tenderly nursed and cared for several days, until he was taken to the field hospital.

My brother had a perfect horror of going to the hospital, and insisted on staying in camp when it was apparent that he was failing every day. He staid with the company until the army was ready to move on the campaign to Corinth, and insisted that he was able to march with the regiment. He fell in with the company with his knapsack, gun and accoutrements, and started on the march, only to fall behind the first mile. I dropped back with him and encouraged him by first carrying his gun; he went on a little farther and gave out again. After resting awhile I took his knapsack and accoutrements and he went a little farther and gave out again. We sat down beside the road until darkness began to overtake us, when an orderly came along, piloting our regimental teams, 
and told us that the regiment had gone into camp about two miles beyond, pointing the direction they were. The teamster took my brother's gun and knapsack, but refused to let him ride, as he had such a load, and had strict orders not to let any one ride. We started through the woods to camp in the direction indicated by the orderly, leaving the traveled road. We were not yet off the battlefield, when darkness overtook us; it began to rain and we got lost, stumbled and wandered around until finally we could see the camp fires, toward which we started. My brother fell into a shallow trench or grave where some of those killed in battle had been buried. The bodies had been entombed just long enough to become decomposed and there being scarcely any earth over them, he got nearly up to his knees in putrified humanity. I pulled him out amid such a horrible stench that I could scarcely stand it, and we made our way to camp where we arrived about twelve o'clock at night. He smelled so badly that the boys could not stay in the tent with him in that condition, so we stripped him of all his clothing, rolled him up in a blanket and laid him in the tent, as he did not have a change of clothing, and I took his clothes to a creek and washed them out and hung them by the camp fire to dry. He had a burning fever all through the night and was not able to sit up the next morning, so the regimental surgeon sent him back to the hospital in an ambulance.

Until after the battle of Shiloh, the discipline in camp and field had been somewhat lax, and the experience of carelessness and surprise at that time had led the officers to see the necessity of being more strict and watchful for a wary foe, until they had gone almost to the other extreme of strictness and discipline, as they saw the stern fact of a long and pitiless war upon us.

We continued our march and approach to Corinth, skirmishing, fighting, entrenching and advancing every day, and I heard nothing from my brother until about the 10th of May, when word came to me from the rear that he was on the hospital steamer City of Memphis at Pittsburg Landing, dying, 
and wanted to see me. I went to my Colonel, E. W. Rice, and asked him for a two days' leave of absence to go to him. He said he would be willing to grant my request, only that he was afraid I might get captured by the Rebel cavalry, or guerrillas if I went alone, and suggested that I might get detailed as one of the guards to the wagon trains that were hauling supplies from our base on the Tennessee River. I told him I would undertake to do so if he would give me permission and a pass; he did so, and had it approved by General Davies, our division commander. I looked around among the wagon-masters of the different divisions to find one going to the landing, but could not find any going that day, so I made up my mind to go alone and take the night for it. I made my way to the rear of the army and waited for darkness. As soon as it became dusk I started, skirting the roads so as to avoid meeting or being overtaken by guerrillas or bushwhackers. I heard squads of horsemen several times during the night, when I would skulk in the brush or slide behind trees and wait until they passed. It was too dark for me to discern whether they were friends or foes.

I arrived at the outposts at the landing at daylight, having marched over twenty miles by the road, the latter part of the journey being over the battle ground of Shiloh, where I had to pick my way through fallen trees, skeletons of horses, unknown graves and the general debris of the late strife. I encountered a few pickets near the landing, who allowed me to pass.

The gunboats Lexington and Tyler I could dimly see in the dusky fog, anchored in mid-stream, with their black hulls and big guns looking angrily out of the port-holes, guarding the supplies on the bluffs, and the hospital steamer whose bow was stuck in the mud of the bank, with her stern swung out in the stream. It was just getting daylight and there was no stir on board as yet. I stepped upon the gang-plank to go on board, when I was confronted by two guards with fixed bayonets, and cold unfeeling looks, who refused to let me pass. I explained my mission and begged them to allow me to go on 
board, which they refused to do, saying they had positive orders not to pass any one. I asked to see the surgeon or officer in charge, but they said he had not yet got up, so I sat down on the bank and waited. The first officer I saw was a young doctor who came out of the cabin, and began fishing over the stern of the steamer. I hailed him and explained to him my errand and asked him to be allowed to go aboard and see my brother. He said he could not allow me to do so, giving as a reason that men had got on the boats upon one pretext or another, and had gone north on French furlough or deserted - that the orders were not to allow any soldiers on board but the guards, nurses and wounded. I told him I would pledge my word as a soldier and gentleman that if he would grant me an interview with my brother, I would go ashore and return to my regiment at the front at once. I held my pass in my hand and asked him to come and read it for himself, stating that it was given by Colonel Rice and approved by General Davies, but he was inexorable and relentless, and no amount of persuasion would induce him to change or modify his decision; so I sat down sorrowfully on the bank to devise some way to circumvent the orders, or, Micawber-like, "wait for something to turn up."

I realized that whatever was done must be done soon, as my leave of absence would expire on the morrow, and my regiment was over twenty miles away, and advancing. I was tired, hungry and footsure from my all night's march. As I sat there eating hard-tack and raw bacon, and watching the doctor fishing, he would occasionally look at me, and I fancied he was uneasy and that his heart was softening. He finally hailed me and asked me if I could find him some angle-worms for bait. I told him pleasantly I would do my best to do so. I thought if I could find them he would allow me to go on board and see my brother. I dug around the bank with my bayonet, but was unsuccessful, so I went back about half a mile to a field and was fortunate in finding some, and returned and called to him that I had them. He told me to come on board and bring them to him, which I very gladly hastened to do. I 
went again to the gang-plank, and was again stopped by the same guards. I again went and called the doctor, and he ordered them to let me pass. I passed to the stern, handed the bait to the doctor and hurried up the after gang-way to the cabin. It was a very large steamer, the state-rooms were full of sick and wounded, and there was a long row of cots full, on each side of the cabin. I searched for some time among the mass of suffering humanity before I found my brother, and when I did I scarcely knew him, he was so emaciated, weak and low, as to be hardly able to speak. He was entirely overcome when he saw me; we clasped hands, and I waited for him to grow calm and get strength enough to talk, which seemed a long time. I was so overeome with grief that I dared not trust myself to speak, and we did nothing for some time but look tearfully into each other's eyes. I could see plainly that I should see him no more after this interview, for the mark of death was plainly upon his brow.

We finally got calm and talked a little; with tearful eyes, and a weak and nervous convulsive motion of his lips, he told me he was aware he had not long to live and was so glad I had come to see him. He was about delivering a message for me to send to mother and the folks at home, when an officer and a detail of soldiers came down the aisle and with a braggart's important air, which broke so harshly on our feelings of grief and affection, absolutely drove me from the boat at the point of their bayonets, in the face of my dying brother's pleading and imploring helplessness and my begging to allow him to finish his last message and to bid me good bye; but it was of no avail; I was mercilessly thrust ashore and I never saw him again.

I saw over four years of service in the war, two and a half in the ranks and the remainder of the time as a commissioned officer, always in the very front, but this was the hardest thing $I$ ever have had to bear, either in war or peace.

I realize that after the surprise, the confusion and demoralization during the battle of Shiloh, it was necessary to have strict orders and thorough discipline, but in the face of all this, 
conceding everything, as time has softened many things and explained others, I still think, and always expect to, that for a cowardly, cold-hearted piece of meanness, that capped the climax; and I shall always think that nobody but cowardly officers and soldiers who skulked and sought duty in the rear, would ever be guilty of such acts. They certainly might have discriminated in their orders enough to allow my dying brother to finish his message to our widowed mother.

He died on the 12th of May, 1862, among strangers, without a friend to comfort him, on the hospital steamer City of Memphis, on his way to Keokuk hospital, and was buried on the banks of the Mississippi River, below Quincy.

Could he have only survived to reach home, and laid his suffering and weary head on the mother's bosom that had nourished him to strength and manhood, to go forth to do battle for his country, he would have died satisfied; and what a comfort it would have been to her through all these long years, to have had the privilege of ministering unto him in his last moments!

To this day I have never had the courage to tell our mother the circumstances of his death, and I hope she may never know them.

The recollections of that time, and the circumstances, come back fresh to me over the lapse of a third of a century, with a vividness as though it were but yesterday - and they were my saddest experiences of the war.

There is no doubt that electric cars can easily be made to go a hundred miles an hour, and that inside of ten years more the people of Des Moines will be able to ride to Chicago on an electric car in three hours in the morning, do their shopping, and come home in the evening.-Prof. J. K. Macomber, in Des Moines Register, Oct. 27, 1894. 
Copyright of Annals of Iowa is the property of State of Iowa, by \& through the State Historical Society of Iowa and its content may not be copied or emailed to multiple sites or posted to a listserv without the copyright holder's express written permission. However, users may print, download, or email articles for individual use. 